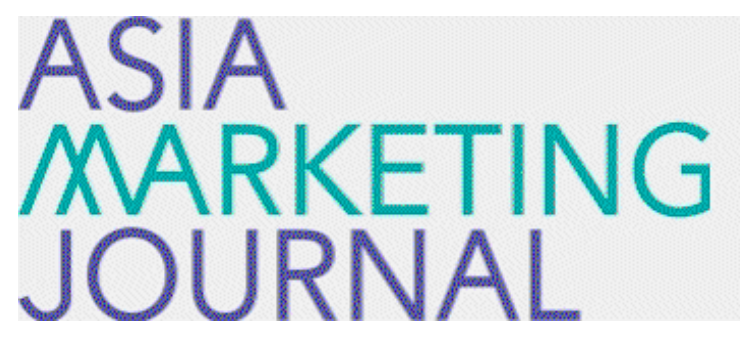

ASIA MARKETING JOURNAL

Volume 2 | Issue 3

Article 1

$9-1-2000$

\title{
국내 대학조직의 기금조성전략
}

\section{Young Kyun Lim}

Follow this and additional works at: https://amj.kma.re.kr/journal

Part of the Marketing Commons

\section{Recommended Citation}

Lim, Young Kyun (2000) "국내 대학조직의 기금 조성전략," Asia Marketing Journal: Vol. 2 : Iss. 3 , Article 1. Available at: https://doi.org/10.53728/2765-6500.1042

This Article is brought to you for free and open access by Asia Marketing Journal. It has been accepted for inclusion in Asia Marketing Journal by an authorized editor of Asia Marketing Journal. 


\title{
국내 대학조직의 기금조성전략: 마케팅 관점에서의 평가*
}

\section{An Evaluation of Fund Raising Strategies in Higher Education: A Marketing Perspective}

임영균(광운대학교 경영학과 교수) lyk5316@daisy.kwangwoon.ac.kr

\begin{abstract}
기금조성은 대학이 활용가능한 중요한 재원확보수단이다. 그럽에도 불구하고 국내 대학의 경우 기금조성 성과는 매우 미흡한 실정이며 이에 대한 연구 역시 체계적이지 못하며 지극히 소수만이 발표되고 있다. 본 연구는 대학의 효과적인 기금조성을 위한 전략적 방향을 마케텅 관점에서 제시하고 있다. 국내 55개 4년제 대학의 기금조성부서장을 대상으로 한 서베이 분석결과, 국내 대학의 기금조성활동은 대체로 도입기에 있으며, 그 성과가 매우 저조한 것으로 나타넜다. 본 연구는 기금조성에 있어 마케팅 관점에서의 접근, 특히 시장지향성과 체계적인 장기전략계흭의 수립이 기금조성 성과와 매우 밀접한 관련을 맺고 있으며, $\mathrm{CEO}$ 와 대학구성원의 몰입이 기금조성 관련변수에 광범위하게 영향을 미치고 있음을 확인하고 있다. 본 연구는 향후 기금조성관련 연구를 촉진하기 위해 기금조성모형과 연구문제를 제시하고 있으며, 대학의 정책입안자에게 필요한 경영압시도 제공하고 있다.
\end{abstract}

* 논문접수: 00.08 게재확정: 00.10

이 논문은 1998년도 학술진홍재단 지원에 의하여 연구되었음(KRF1998-001-C00791) 


\section{1. 연구의 배경}

현재 우리 나라의 교육시장은 매우 교란적이고 역동적이며 이질적인 시장으로 전환 되고 있다. 이로 인해 대학간의 경쟁은 날로 치열해지고 있으며 최근 수년간 국내 대 학은 생존과 발전읍 위해 나륨대로 장. 단기 계힉울 수립하여 대학의 위상을 재정립하 는 한편, 기존 교왁 프로그램과 조직을 개편하고, 신설학과 혹은 신규 교육 프로그램을 개발하여 새로운 교육시장으로의 진출을 모색하고 있다 (임영균 1995, 1996). 국내 대학 이 장 단기 발전계혁을 수립하고 실행함에 있어 가장 고민하고 있는 부분은 전략 수행에 필요한 투자 재원의 확보라고 할 수 있다. 정부의 대학에 대한 재정지원규모가 선진국에 비해 현저히 낮고, 둥록금과 정원이 규제되고 있는 상황에서 국내 대학은 재 원확보를 위해 정부의 국고지원 확대를 요구하는 한편, 대학 스스로 행정과 경영을 합 리화하고, 기업, 학부모, 동문 둥을 대상으로 기금조성을 꾀하고 있다 (이종훈 1999).

기금조성(fund raising)은 대학이 활용가눙한 중요한 재원확보수단이다. 기금조성은 수 입중대방안의 하나로 여타 방안과는 달리 정부당국의 규제률 받지 않고 대학이 독자적 으로 실행가능하며, 비용절감방안(예를 들어 인력감축, 인건비절감 둥)과는 달리 자원 배분에 따른 부작용이 적다는 븍징을 지니고 있다. 대학에서의 기금조성이 특히 중요한 이유는 근본적으로 대학이 비영리조직이기 때문에 지속적으로 외부로부터의 자금을 필 요로 하고 있고, 선진국의 경우 많은 대학이 자신의 명성을 높이고 경쟁우위를 확보하 기 위한 유효한 수단으로 이를 할용하고 있기 때문이다(Cook and Lasher 1996). 미국의 대다수 총장은 대학의 재정문제를 해결하는 수단으로 비용절감보다는 수입증대가 중요 하다고 믿고 있으며, 이에 따라 학문적 관리자보다는 기금조성자로서 자신의 역할올 받 아들이고 있다 (Hamlin and Hungerford 1988-89).

국내 대학도 최근에 이르러 기금조성의 중요성을 인식하고 이를 위해 많은 노력을 기울이고 있지만 안타깝게도 일부 명문사립대학을 제외하고는 상당수의 대학이 10 억원 미만의 매우 저조한 성과를 보이고 있다(중앙일보 1998). 국내 대다수의 대학은 장기적 인 재정자립은 고사하고, 중. 단기적인 과제의 수행에도 절대적으로 모자라는 수준의 성과를 보이고 있으며, 기금조성에 있어 성공적인 것으로 평가되고 있는 일부 대학의 경우에도 전체 재정수입에서 기금조성에 의한 수입이 차지하는 비중은 매우 낮은 것이 현실이다.

국내대학을 대상으로 한 기금조성관련 연구는 지극히 소수만이 발표되고 있으며, 이 들 연구는 기금조성 현황율 기술하고 있거나 전술적 기법을 소개하고 있다는 한계를 지니고 있다(방명숙 $1994,1995,1998)$. 본 연구는 효과적인 기금조성을 위해 국내 대학 이 취해야 할 전략적 방향을 마케팅 관점에서 제시하는 데 그 목적이 있다. 이를 위해 본 연구는 1970년대에 이미 심각한 자원감소와 치열한 경쟁을 경험한 바 있는 미국 대 학의 기금조성에서의 사례와 이론을 토대로 기금조성 성과에 영향을 미치는 요인을 밝 히고 있으며 이률 국내 대학에 대한 실증분석을 붕해 확인하고 있다. 구체적으로 본 연구에서는 1)대학의 기금조성에 있어 시장지향적 접근이 이루어지고 있는가, 2)기금조 성 전략계힉이 체계적으로 수립되어 있는가, 3)전략수행을 위한 기금조성조직은 효과적 
으로 설계· 운영되고 있는가, 4)충장과 재단이사 나아가 전체 대학구성원의 기금조성에 의 몰입이 이루어지고 있는가, 5)기금조성 성과는 얼마나 만족스러운 것인가, 6)기금조성 성과의 선행변수와 성과간의 관계는 어떠한가 둥을 주요 연구문제로 다루고 있다.

\section{2. 주요 개념과 분석의 틀}

\section{1.기금조성의 의의}

기금조성(fundraising)에 대한 학자간의 뿡일된 정의는 없다. 기금조성의 개념은 역사적으 로 일련의 단계를 거쳐 발전되어왔다. 초기 단계에서는 부유층의 관심과 동정을 끌고 이들에게 ‘구결(begging)'하는 것으로 기금조성의 성격이 주어졌으며, 이후에는 후원자 로부터 정기적으로 기금을 모집(collection)하는 단계, 특정한 개인이나 집단에게 체계적 인 기금조성활동의 책임을 부여하는 캠페인(campaigning) 단계, 최근에 이르러는 상이한 계충의 고정 기부자를 확보해 나가는 발전(development)의 개념으로 변해가고 있다 (Kotler and Andreasen 1991), 현재 대확의 기금조성은 발전이나 향상(institutional advancement) 의 개념과 혼용이 되거나 이들 개념의 하위개념으로 정의되고 있다.

기금조성에 대한 정의는 학자간에 차이가 있으나 기금조성의 구성요소에 대해서는 대부분 의 학자가 동의하고 있다. 기금조성은 조사(research), 교화(cultivation), 간청(solicitation), 감사 (recognition)의 네 단계로 구성되며, 대규모 기부(major gifts)의 경우, $25 \%$ 의 조사, $60 \%$ 의 교화, $5 \%$ 의 간청, $10 \%$ 의 감사로 구성된다 (Wood 1989). 본 연구에서는 기금조성을 "기부의 대상이 되는 조직이 개인, 기업, 재단으로부터 금전적 기부를 간청하고 수용하는 목적지향적 과 정”(Kelly 1991, pp.79-80)으로 정의하기로 한다.

\section{2.기금조성 성과의 결정요인}

과거 20 년 간의 기존 문헌을 검토해 보면 성공적으로 기금조성이 이루어지기 위해서는 몇 가지 특성이 대학에 요구되고 있다. 대학이 처한 상황에 따라 기금조성이 지니는 의의가 다 르기는 하지만 일반적으로 기금조성이 성공하기 위해서는 무엇보다 기금조성 부서와 여타 부서, 나아가 대학 구성원간의 팀웍이 중요하며, 대학의 총장이 기금조성에 있어 핵심적인 역할을 수행하여야 하고, 소규모 기부자보다는 대규모 기부자에 대한 지속적인 접근노력이 중요하며, 장기적으로 대학의 학문적 위상과 명성올 높이는 것이 중요하다고 할 수 있다 (Cook and Lasher 1996).

<표 1>은 기존의 문헌과 사례분석을 통해 밝혀진 기금조성성과의 선행변수들을 열거하고 있다. 이들 변수는 크게 대학변수(institutional variables)와 환경변수(environmental variables)로 구분할 수 있다. 대학변수는 대학이 어느정도 통제가눙한 반면, 환경 변수는 개별 대학이 대 체로 퉁제불가능한 요인듈이라 할 수 있다. 대학변수는 대학자체의 구조, 문화, 전략적 특성 과 배경톡성으로 구분할 수 있으며, 여기에는 총장과 재단이사, 기금조성 부서장 둥 기금조 
성 책임자의 개인적 특성도 포합되어 있다. <그림 1>은 이들 선행변수가 기부자 반응에 영 향을 미치며, 기부자 반웅에 의해 기금조성의 성과가 결정되고 있음을 보여주고 있다.

비록 대학의 기금조성 성과가 환경적인 요인에 의해 영향을 받는 것이긴 하나 본 연구에 서는 기본적으로 기금조성 성과가 대학이 어떻게 기금조성활동을 수행하는 가에 의해 결정 되며 특히 대학이 마케팅 관점에서 기금조성활동을 수행하고 있는가가 중요하다는 가정을 하고 있다. 따라서 <표 1>의 요인 중 본 연구에서 관심을 가지고 있는 요인은 환경변수를 제외한 1 에서 8 까지의 요인들, 즉 대학이 퉁제가능한 요인들이라 할 수 있다.

<그립 1> 기금조성 성과와 선행변수와의 관계

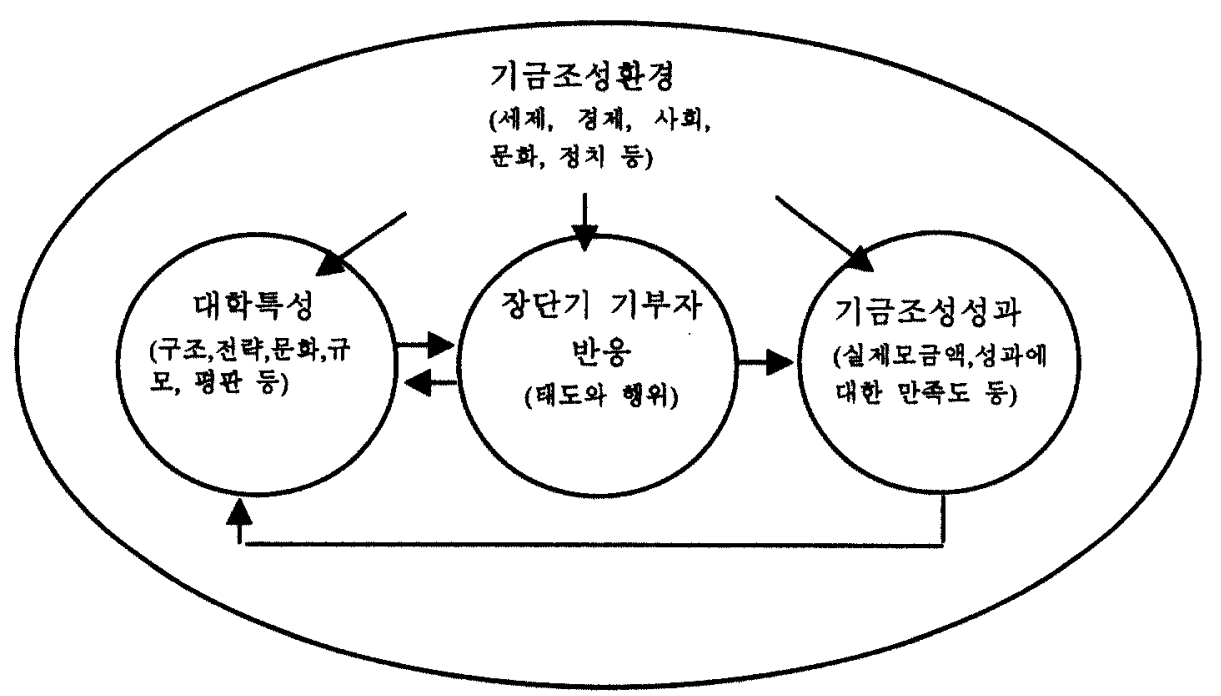


<표 1> 대학의 기금조성성과에 영향을 미치는 요인

\begin{tabular}{|c|c|c|}
\hline 구 분 & 요 인 & 내 용 \\
\hline \multirow{8}{*}{ 대학변수 } & 1. 리더쉽 & $\begin{array}{l}\text { 훙장, 재단이사, 학장, 자원봉사자, 스탭 둥의 리더 } \\
\text { 넙, 구체적으로: } \\
\text {-기금조성에의 참여의지/욕구 } \\
\text { - 기금조성능력, 기술, 적성(세일즈맨쉅) } \\
\text {-기금조성 노력, 몰입, 성실성 } \\
\text { - 대학의 효과적 관리 } \\
\text { - 대학의 재정적 생존능력 } \\
\text {-자원의 효과적 운용 } \\
\text { - 기부자에 대한 확신 세공 } \\
\text {-초기 기부에 대한 감사표시 }\end{array}$ \\
\hline & 2. 기부자 기반 & 기부자의 인적 기반/재정적 눙력 \\
\hline & 3. 대학사명 & 대학사명의 명료성과 강점 \\
\hline & 4. 인적 관계 & 기부자와 대학관계자간의 궁식, 비공식적 관계 \\
\hline & 5. 기부자 관여 & 대학생존에 대한 기부자의 관심과 노력 \\
\hline & 6. 대외적 특성 & 대학의 명성, 평판, 이미지 \\
\hline & 7.대학 및 발전프로그램의 륵성 & $\begin{array}{l}\text { 대학 및 발전프로그램의 역사, 성숙도, 일관성, 전봉. } \\
\text { 구체적으로: } \\
\text {-학문프로그램의 폭과 범위 } \\
\text {-적절한 정책과 지원구조 } \\
\text {-적절한 예산과 스탭 } \\
\text {-정착된 기부습관 및 패턴 } \\
\text {-역대 충장간의 일관성 } \\
\text {-역대 기금조성부서장간의 일관성 } \\
\text {-기금조성의 질적 수준에서의 일관성 } \\
\end{array}$ \\
\hline & 8.기부자와의 의사소통 & $\begin{array}{l}\text { 기부자와 대학간의 빈번하고 쌍방향적인 효과적 의 } \\
\text { 사소통 프로그램 }\end{array}$ \\
\hline \multirow{4}{*}{ 환경변수 } & 9.기부행위에 대한 사희적 인식 & $\begin{array}{l}\text { 기부행위의 종교적 가치, 지역사회의 인식, 기부 전 } \\
\text { 퉁의 정착화 }\end{array}$ \\
\hline & 10.일반대중의 지속적 확신 & $\begin{array}{l}\text { 대학 및 비영리조직의 가치와 성실성에 대한 일반대 } \\
\text { 중의 학시 }\end{array}$ \\
\hline & 11.경제/국내 상황 & \\
\hline & 12.조세정책 & 기부와 관련된 국세, 지방세법 \\
\hline
\end{tabular}

자료: Cook and Lasher (1996)

\section{3.기금조성에서의 마케팅 관점}

대학은 비영리조직이지만 마케팅 관점에서 자신의 활동을 수행할 때 보다 바랍직한 결과 를 얻을 수 있다. 마케텅 관점은 이미 미국의 많은 대학에 의해 보편적으로 받아들여지고 있는 경영 패러다임이라고 할 수 있다(Kotler and Fox 1985). 기금조성에 있어 마케팅 관점이 처음 제시된 것은 Lord(1983)에 의해서다. Lord는 기금조성에 있어 중요한 것은 기부자에게 만족을 제공하는 것이라고 보며 성공적인 기금조성을 효과적인 마케팅과 본질적으로 같온 것으로 본다. 기금조성은 마케팅과 같이 교환행위를 본질로 하며(Silberg 1987; Burke 1988; Brittingham and Pezzullo 1990), 마케팅의 개념과 전략, 조사기법은 다방면의 기금조성에 활용 되고 있다(Carbone 1986; Steinberg 1987).

대학의 기금조성에 있어 마케팅 관점율 체계화하고 있는 것은 Kotler와 그의 동료들에 의 
해서다. Kotler and Andreasen(1991)은 비영리조직의 기금조성 관점이 제품지향적 단계(product orientation stage)로부터 판매지향적 단계(sales orientation stage)률 거쳐 전략적 마케팅 단계 (strategic marketing stage)로 발전하는 것으로 보고 있다.

기금조성에 있어 제품지향적 판점이란 하나의 조직이 개인이나 사회에 제공하는 가치에 비추어 볼 때 기부자가 조직을 지원하는 것이 당연하다고 본다. 대학의 사회적 기능에 비추 어 볼 때 대학이 사회에 지원을 요청하는 것은 당연하며 사회는 대학을 지원해야 하는 의무 를 가진 것으로 본다. 제품지향적인 단계에 있는 조직은 소수의 충성적인 독지가에 의해 대 부분의 기금이 조성되며 나머지 기금은 자원봉사자에 의해 조성된다.

판매지향적 관점에서는 하나의 조직이 잠재기부자로부터 기금을 확보하기 위한 노력올 보 일 때만 기금조성이 가능한 것으로 본다. 대학은 발전부서와 같은 기금조성부서를 조직하고 인력을 확보하여 잠재기부자에 대한 접근을 시도하며, 기부자에 대한 일방적인 의사소통전 략에 크게 의존하는 성향이 있다. 기금조성부서는 단순히 기금조성의 임무만을 수행할 뿐 대학의 정책이나 여타 부서의 활동에 이렇다할 영향을 미치지 못한다. 이들 판매지향적 조 직은 고객보다는 자신을 먼저 생각하며, 고객이 원하는 것올 모르거나 알면서도 무시하고, 지나치게 광고와 PR둥 촉진수단에 의존하며, 고객조사를 거의 실시하지 않고, 보수적인 의 사결정과 한 두가지의 전략에 의존하며, 경쟁에 익숙하지 않거나 무시하는 성향이 있고, 마 케팅 능력보다는 제품이나 서비스에 의한 지식에 의해 인력을 선발하는 성향이 있다 (Andreasen 1982).

마케팅 관점에서 뷸 때 기금조성은 기부자 시장에 대한 이해를 토대로 기부자 시장을 세 분화하고 각각의 기부자 시장별로 잠재기부능력을 측정하며, 기금조성부서의 관리자에게는 각각의 시장을 개발하는 책임이 주어진다. 마케팅 관점에서는 기부자와 대학간의 교환과정 (exchange process)이 분석의 초점이 된다. 교환은 마케팅의 본질이며, 따라서 마케팅 관점에 서는 교환당사자 간에 어떠한 가치의 교환이 이루어지고 있고, 이들 간의 관계를 어떻게 발 전시켜나가는 것이 서로에게 이로운 것인가를 규명하는 것이 중요해진다. 최근들어 기부행 위에 대한 인식은 이를 순수한 이타행위로 보는 것으로부터, 기부자는 기부금의 대가로 대학으로부터 톡권이나 이익 흑은 명예률 언는 교환행위로 보는 것으로 바뀌고 있다. 따라서 기부자가 대학으로부터 무엇을 원하고 대학은 무엇율 제공할 수 있는가를 이해 하는 것이야말로 기금조성전략의 수립에 있어 필수적으로 고려되어야 할 요소라 할 수 있다.

기금조성의 개넘이 구절에서 발전의 개녑으로 변화해나감에 있어 중요한 것은 어떠 한 형태이건 기부자에 대한 보상이 있어야만 이들이 기금을 내놓계 된다는 사실을 대 학이 깨달게 되었다는 점이다. 기금조성은 기부자가 대학에게 기금을 지속적으로 제공 하고 이 과정에서 대학으로부터 무언가 가치있는 것을 흭득하는 과정으로 정의이며, 따 라서 대학은 기부자의 입장에서 뷸 매 자신을 지원할 만한 가치가 있는 것으로 보이게 하는 것이 중요하다. Cook and Lasher(1996)는 사희교환이론(social exchange theory)에 입각 하여 대학의 기금조성을 대학과 기부자간의 상호의존(interdependence)에 의한 교환과정으로 보고 있다. 상호의존적인 판계에서는 교환의 주체인 쌍방이 상대방에 대하여 가지는 힙에 의해 자신이 얻게 될 성과가 결정된다(Pfeffer and Salancik 1978). 이러한 의미에서 대학의 기 금조성 성과가 어떻게 결정되는가에 대한 연구는 기부자와 대학간의 상호의존관계를 분석하 는 것으로부터 시작하여야 한다. 톡히 기부자로부터 기부행위라는 반웅을 얻기까지 대학 혹 
은 기금조성 책임자가 미치는 영향을 분석하는 것이 중요하다.

그렇다면 마케팅 관점에서 보았을 때, 기금조성에 있어 성공적인 대학과 그렇지 못한 대 학을 뚜렷이 구별짓는 요소는 무엇인가. 본 연구에서는 기금조성활동의 성공여부를 결정짓 는 요소를 크게 (1)시장지향적 접근, (2)체계적인 전략계획수립, (3)효과적인 조직구조, (4)조직 구성원의 기금조성에의 몰입의 네 가지로 보고 있다.

\subsection{1 시장지향적 접근(market-oriented approach)}

기금조성활동이 성공하기 위해서는 동문, 학부모, 일반대중, 기업체와 사회재단 둥 기부자 별로 기부행위와 관련하여 이들이 자신의 기부행위로부터 어떠한 혜택을 얻고자 하는가를 이해하고 있어야 한다. 또한 기금조성계획은 무엇보다 기부자 시장을 분석하여 목표 기부자 시장을 선정하고 각각의 시장별로 수립하는 것이 바랍직하다. 목표기부자 시장에 대한 이 해는 마케팅전략의 수립에 있어 가장 기본적인 요구이며, 이는 전략계흭수립과정의 각 단계에 유용한 정보를 제공해준다. 예를들어 Leslie and Ramey (1988)은 대학의 재정적 어려움을 호소하는 구걸전략(poverty strategy)이 동문들에게는 효과적일지 몰라도 일반대 중에게는 그다지 효과적이지 못하며, 대학과 기부자간의 장기관계형성이 중요한 것으로 보고 있다.

기금조성의 도입기에 있는 대학의 경우에는 저변확대롤 위해 볼참자를 대상으로 인터뷰 둥을 실시하여 그 원인을 찾는 등 체계적이고 지속적인 노력이 중요하다(Marks 1987). Stanford 대학의 경우, 잠재기부자의 파악을 위해 3 년간 체계적인 노력을 기울였으며, 일정기간(5년에서 10 년)이 경과한 후 잠재기부자를 재평가하고 있다.

앞서의 논의는 마케팅 관점을 구현함에 있어 기금조성활동에서의 시장지향성(market orientation)과 철저한 마케팅 조사, 특히 사전 가능성 조사(feasibility test)가 매우 중요한 의미 를 지니고 있음올 암시한다. 기금조성활동이 성공하기 위해서는 기부자 시장에서의 기부자 와 경쟁대학에 관한 중요 정보를 입수하고, 이를 관련부서에 배포하여 적절한 반응전략올 설계, 실행하는 것이 중요하며 면밀한 마케팅조사를 실시하여야 한다.

특히 기금조성 가능성에 대한 사전조사는 잘못된 시작을 예방하는 한편 기부자의 관심을 찾아주며, 현실적으로 가눙한 조언올 제공하고, 실제로 예상 밖의 성과를 가져다주는 중요한 기능을 한다 (O'Shea 1994). 가능성 조사는 주요 기부자, 잠재기부자, 의견선도자가 개인적으 로 기금조성 면담자와 만나 현재 계혁중인 기금조성 캠페인을 검토하게 하는 한편, 대학에 대한 지원 및 기금조성목적과 관련된 구조화된 설문에 웅답하도록 한다. 가능성 조사에 참 여하는 자는 이를 종합평가한 결과를 캠페인 의사결정자에게 제공한다. 재단이사회나 총장 은 가능성조사의 결과를 토대로 최종적으로 캠페인 실시여부를 결정하게 된다.

가눙성 조사는 대학내 기금조성부서에서 실시하기도 하지만 대부분의 기금조성자는 외부 기관(기금조성 전문기업)에서 실시하는 것이 편견이 없고 신뢰적이며 포괄적이라는데 동의 하고 있다. 기금조성 경헙이 부족한 대학의 경우에는 가능성조사, 기금조성책임자의 탐 색, 스탭에 대한 교욕, 필요시 자문 둥의 기능올 수행하는 기금조성 컨설턴트의 활용을 적극 검토할 필요가 있다(Wise 1994).

\subsection{2 체계적인 전략계힉수립(systematic strategic planning)}

마케팅 관점의 또다른 특징은 모든 마케텅활동이 체계적인 전략계힉에 의해 수행된다는 
점이다. 기금조성을 포함한 모든 대학의 기늉과 할동은 장기발전계힉의 일환이고 기금조성 활동도 전략적으로 계힉되고 실행, 관리되어야 한다. 실제로 미국의 경우 대학의 기금조성활 동은 기업의 경영할동과 마찬가지로 전략계혁에 의해 이루어지고 있다.

기금조성활동은 1)환경분석에서부터 기금조성목표와 전략의 수립, 조성프로그램의 개발과 실행, 퉁제에 이르는 일련의 전략적 마케팅계힉에 의해 수행되어야 하며, 2)대학차원의 장기 발전계힉에 의해 뒷받침되어야 한다.

전략적 기금조성계혁: 기금조성이 성공하기 위해서는 기금조성에서부터 조성된 기부 금의 관리에 이르기까지 일련의 활둥을 전략적이고 체계적으로 개발할 필요가 있다. 기 금조성계힉의 수립에 있어서는 기부자에 대한 분석과 기금조성목표와 전략의 수립, 기 부자 시장에서의 대학의 위상정립, 기부자와의 지속적인 의사소통 둥 전략적 마케팅 관 점(strategic marketing orientation)이 요구된다.

대학과 같은 비영리조직에 있어 전략적 계힉시스템이 매우 중요한 이유는 전략적 계 힉시스템에 의해 조직의 사명과 목표가 뚜렷해지고, 의사결정 권한이 집중되며, 성과 지표 가 분명하기 때문에 관리자가 기금조성에 펄요한 기능이나 기금조성 수준에 따라 의사 결정을 효과적으로 수립, 실행, 퉁제할 수 있기 때문이다(Bryson 1988; Lindahl 1992). 구 체적으로 Lindahl(1992)은 기금조성에서의 전략계힉수립이 1)모금과정에 주어진 가정과 제약 조건 하에서 대학이 가장 효율적으로 기금 조성 자원을 활용할 수 있게 하며, 2)목표가 현실 적으로 주어짐으로써 기금조성 인력의 성과를 보다 잘 판단할 수 있게 하고, 3)계획수립과정 에 기금조성 인력으로 하여금 최종 계힉에 보다 적극적으로 참여하게 하고, 4)기부자시장의 동정과 활동프로그램이 어떻게 기능을 수행하고 있는가률 알 수 있게 하고, 5)전체 기금조성 활동에 있어 보다 중요한 이슈가 무엇인지를 검토하게 해주는 것으로 보고 있다.

Duronio and Loessin(1991) 역시 전략적 계흭수립이 효과적인 기금조성에 있어 중요한 것으로 보고 있다. 이들에 의하면 성공적인 대학의 경우 공식적이건 비공식적이건 전략 계흭수립이 이루어지고 있으며, 비록 비공식적인 전략수립을 하고 있는 대학의 경우에 도 기금조성을 장기 전략적인 관접에서 다루고 있는 것으로 밚히고 있다. 또한 많은 대학이 대규모 캠페인에 있어서는 공식적인 전랴 계혁을 보다 적극적으로 활용하고 있 으며, 전략계힉이 지니고 있는 유용성에 대부분의 기금조성 관리자가 긍정적인 견해를 가지고 있는 것으로 나타나고 있다.

대하의 장기전략계혁과의 연계성: 기금조성은 대학의 장기전략계흭 상의 활동을 지 원하는 가장 중요한 요소다. 기금조성활동은 대학의 문화와 욕구, 사명올 반영하고 있 는 장기전략계혁(long-range strategic planning)에 의해 됫받침되어야 한다 (Blong and Bennett 1991). 장기전략계힉이 수립되어 있는 경우 대학은 기금조성에 있어 크게는 예 기치 못한 환경변화에 신축적으로 대웅할 수 있으며, 작게는 잠재기부자의 파악과 이들 과의 원할한 의사소퉁이 가능해지는 둥 다양한 이점을 가지게 된다 (Kotler and Fox 1985). 기금조성온 학생이나 교수, 동문, 혹온 체육부에 이르기까지 대학의 전반적인 발 전계휙과 연계되어 있을 때에 보다 용이하게 진행될 수 있다. 잠재기부자가 공감하는 대학의 장기발전계흭은 이들에게 대학의 투자가치를 일깨우고 신뢰감을 조성하는 데도 기여하게 된다. 설령 단기간 진행되는 기금조성캠페인이라 할 지라도 장기적인 대학발 전 프로그램의 일환으로 이해되어야만 한다. 
대학의 총장은 기금조성의 목적을 세우기 전에 우선 학장이나 학과장들에 대해 이들이 수 행하고자 하는 활동이 무엇이며 필요한 자금을 스스로 얼마나 확보할 수 있는지를 알아보아 야 한다. 물론 이들 활동은 단위부서의 장기전략계획에 포함되어 있어야 하며 우선순위가 결정되어 있어야 한다. Wise (1994)는 기금조성캠페인이 실시되기 이전에 기금조성캠페인 에서 추구하는 목표가 대학이 추구하는 목표에서의 우선순위와 대학의 조직문화를 반 영하고 있는가를 반드시 검토되어야 할 항목으로 보고 있다.

\subsection{3 효과적인 조직구조(effective organizational structure)}

기금조성조직은 대학의 규모에 따라 형태가 다양할 수 있다. 소규모 대학의 경우에 는 총장이나 개인이 기금조성의 책임을 맡을 수 있으나, 대규모 대학의 경우에는 사무 직원과 자원봉사자를 포합하여 수백명에 이르는 인력이 동원되기도 한다.

일반적으로 기금조성조직은 재단이사회, 총장, 기금조성부서, 운영위원회와 자원봉사 대로 구분할 수 있다. 재단이사회는 대학의 재정상태에 대한 궁극적인 책임을 지고 있으며 따라서 투자방향의 설정과 기금조성전략에 필요한 모든 활동올 결정짓는다. 총장은 재단이 사희에서 부여한 권한으로 기금확보의 총책임자로서 잠재 기부자 시장과의 접촉을 통해 기 부금 헌납을 요청하게 된다. 발전담당 부총장은 기부금모금계흭을 수립하며 총장과 함께 기 부금 모금에 나선다. 기부금 모금과 관련된 일상업무는 발전 사무국장이 총괄함으로써, 발전 부총장이 주로 전략계힉의 수립에 시간을 소비할 수 있도록 도와준다. 사무국장 이하의 조 직은 기부자 시장, 마케팅 도구, 단과대, 혹은 지역별로 구성된다.

기금조성에 있어서는 발전사무국내에 운영위원회(steering committee)를 두는 것이 바람직하 다. 운영위원회는 모금활동의 전략계흭을 수립하고 이를 실행하기 위한 제도와 절차를 심의 한다 (Lindahl 1992). 구체적으로 이들은 모금활동기간을 설정하고, Delphi 계휙집단의 구성원 올 선정하며, 주요 목표 기부자시장을 결정하는 역할을 수행한다.

한편, 대학은 기금조성에 있어 동문이나 학부모, 교수와 직원, 학생으로 구성된 자원봉사 대를 활용할 수 있다. Stanford 대학의 경우에는 1 인당 천불을 매년 기부하는 Inner Quad라는 특별 기금조성 프로그램을 위해 전국적으로 250 명의 자원봉사자를 활용하고 있으며, 이들은 8명의 사무직원과 정기적으로 접촉하고 있다 (Lovelock and Weinberg 1977).

대다수의 기금조성 실무자와 일부 학자들은 자원봉사대의 적극적인 참여가 기금조성 의 성공가능성을 높이는 것으로 믿고 있다 (cf. Snelling 1986). 그러나 Duronio and Loessin(1991)의 실중분석 결과는 성공적인 대학에 있어 자원봉사대가 수행하는 역할에 있어 많은 차이가 있는 것으로 보고하고 있다. 기금조성에 성공한 대학의 상당수에 있 어 기금조성 부서장이 자원봉사대의 참여를 유도하는데 관심으로 전혀 가지고 있지 않 을 뿐만 아니라, 설령 자원봉사대를 활용하고 있는 대학의 경우에도 이들의 역할이 매 우 미미한 것으로 드러넜다. 심지어 일부 대학은 의도적으로 자원봉사대의 참여를 극소 화시키는 것으로 나타나고 있다. 이러한 결과는 앞서의 주장과는 상반된 것으로 기금조 성이 성공하기 위해 반드시 자원봉사대가 필요한 것은 아니며, 해당 대학의 기금조성 역사와 학내 여타 활동에 있어 자원봉사대가 어떠한 역할을 수행하여 왔는가에 따라 기금조성에 있어 자원봉사대의 중요성이 결정되는 것으로 볼 수 있다.

\subsection{4 기금조성에의 몰입(commitment to fundraising)}

기금조성이 성공하기 위해서는 대학에서 기금조성이 지니는 가치에 대한 궁통된 인식과 
태도를 기반으로 충장과 재단이사, 교수. 직원, 학생, 학부모, 동문 둥 구성원의 몰입이 요구 된다. 기금조성에의 물입을 높이기 위해서는 무엇보다 기금조성자로서 1)충장, 2)재단이사, 3) 기금조성부서장의 역할이 매우 중요하다. 이들은 목표기부자시장의 특성과 대학의 장기발전 계흭 및 기금조성 프로그램에 대해 충분한 지식을 가지고 있어야 한다. 또한 이들의 기금조 성성과를 평가하고 보상하기 위한 체계를 확립하여 기금조성에 대한 동기부여가 제공되어야 한다.

충장: 대학의 $\mathrm{CEO}$, 튝히 총장은 기금조성에 있어 가장 핵심적인 역할을 수행한다. 역사적 으로 오랫동안 기금조성은 대학충장의 중요한 역할 중의 하나로 주어져왔다. 최근에는 기금 조성 컨설턴트와 전문스탭이 출현하고 있지만 대학총장의 기금조성자로서의 중요성은 여전 히 감소하고 있지 않다(Cook and Lasher 1996). 그러나 기금조성자로서 대학의 CEO에 대한 학 문적 연구는 1988년에 첫 논문이, 1989년에 첫 저서가 발간되었을 정도로 최근까지 거의 이 루어지지 않았다. 이는 기금조성 자체에 대한 연구가 70 년대에 와서야 학문적 관심의 대상 이 되었다는데서 그 이유를 찾을 수 있다.

이제까지의 연구를 종합해보면 기금조성자로서 대학의 CEO가 지녀야 할 특성 중 가장 중 요한 특성은 기금조성자로서의 리더윕이라고 할 수 있다. Duronio and Loessin(1991)의 실중분 석은 기금조성에 있어 성공적인 대학의 거의 모두에 있어 총장이 강력한 리더쉅을 발휘하고 있음을 밝히고 있다. 여기서 리더쉅의 개념은 세일즈맨윕, 성실성, 기금조성에의 참여의지와 같은 개인적 특성과 팀웍조성, 효과적 조직관리, 직무처리 둥 조직과 관련된 특성으로 구분 할 수 있다 (Cook and Lasher 1996). 기금조성에서의 리더섭을 발휘하기 위해 대학의 CEO에 게 요구되는 과업으로는 (1)대학의 비견과 사명을 제시하고, (2)재단이사와 교수 직원으로부 터 기금조성에 대한 지지 분위기를 조성하며, (3)기금유치의 선례를 남기는 한편 이에 많은 시간을 투자하고, (4)기금조성 전략계흭을 수립하고 실행하는 것을 들 수 있다(Glass and Jackson 1998; Duronio and Loessin 1991; Fisher and Quehl 1989).

재타이사: 재단이사가 기금조성에 참여할 수 있는 방법은 크게 (1)자신이 기부행위를 하거 나, (2)잠재기부자률 파악하는 것을 돕거나, (3)기금조성을 지원하는 대학의 정책을 결정하는 것으로 구분할 수 있다. 기금조성에 있어 재단이사의 이러한 역할은 국공립대학보다는 주로 사립대학을 중심으로 요구되어 왔다. 그러나 국공립대학의 경우에도 일부 대학은 재단이사 의 선임에 있어 기금조성 능력을 중요한 요소로 고려하고 있다.

재단이사의 역할과 관련하여 Duronio and Loessin(1991)은 재단이사의 기금조성활동에의 관 여나 참여가 기금조성의 성공요인은 아닌 것으로 보고하고 있다. 이러한 결과는 재단이사의 역할이 중요하다는 기존의 주장이나 상식과는 어긋나는 것으로 보인다. 재단이사의 참여정 도와 기금조성성과와의 관계가 낮음에도 불구하고, 상당수 대학의 기금조성 책임자는 여전 히 재단이사의 참여가 기금조성의 효과성을 높일 것이라는 기대를 갖고 있는 것으로 나타났 다.

기금조성부서장. 기금조성 부서장(chief development officer)은 총장과 함께 기금조성에 있 어 매우 중요한 역할을 수행한다. Worth and Asp(1995)는 기금조성 부서장의 역할을 판매원 (salesman), 촉매자(catalyst), 관리자(manager), 선도자(leader)로 구분하고 있다. 판매원의 관점 은 기금조성 부서장의 역할에 있어 모금 할동을 강조한다. 촉매자로서의 기금조성 부서장은 총장이나 자원봉사자의 기금조성할동을 후방에서 지원하는 역할을 수행한다. 기금조성 부서 
장을 관리자로 보는 견해는 기금조성프로그램과 인력을 조직화하는 내부역할을 강조하며, 선도자로 보는 관점에서는 기금조성 부서장이 단순히 기금조성의 역할만 수행해야 하는 것 이 아니라 대학의 정책결정에 있어서도 일정한 역할을 수행해야만 하는 것으로 본다.

이와 유사하게 Duronio and Loessin (1991)은 기금조성자가 수행하는 역할을, (1)대학정책의 우선순위와 기금조성 목표를 설정하는 경영자(officer)로서의 역할, (2)기금조성에 대한 직접적 인 책입을 지고 모금에 나서는 기금조성자(fund raiser)로서의 역할, (3)기금조성계획의 수립, 실행, 통제를 책임지는 관리자(manager)로서의 역할, (4)기금조성 스탭에 대해 자신의 경험과 지식을 제공하는 스숭(mentor)으로서의 역할, (5)기금조성을 하나의 사업으로 간주하여 이에 따른 위험을 감수하며 새로운 접근방식을 추구하는 사업가(entrepreneur)로서의 역할로 구분 하고 있다.

기금조성 부서장의 역할에 대한 상이한 관점에 따라 기금조성 부서장이 지녀야할 톡성에 대한 관점도 다르게 제시되고 있다. 대체로 판매원과 선도자로서 기금조성 부서장을 보는 관점에서는 대인관계에서의 숙련도(interpersonal skills)와 개인의 카리스마를 강조한다. 반면 촉매자나 관리자로 보는 관점에서는 후방지원에 필요한 기술적 숙련도(technical skills)를 강 조한다. Duronio and Loessin(1991)은 기금조성자가 위의 역할을 모두 수행하는 것은 아니며, 효과적인 기금조성은 기금조성 부서장의 스타일과 강점이 대학의 욕구와 적합(fit)할 때 가 능한 것으로 보고 있다. 예를들어 대학의 기금조성활동이 지지부진한 경우에는 여타 역할보 다 사업가로서의 역할이 중요하며 따라서 비록 기금조성에서의 경헙이나 지식온 부족하더라 도 사업가적 자질을 지닌 인물이 적합한 반면, 단위부서(단과대, 학과 둥)에 산재하고 있는 기금조성활동을 통합조정하기 위해서는 여러 보직올 거친 학내 인사를 활용하는 것이 바람 직한 것으로 보고 있다. 이들의 실중 분석결과는 기금조성에 있어 성공적인 대학 모두에 있 어 기금조성 부서장이 강력한 리더쉽을 발휘하고 있는 것으로 보고하고 있다.

\section{4. 기금조성의 성과변수}

기금조성의 성과를 평가하기 위해서는 다양한 변수가 활용둴 수 있으며, 변수선정에 있어 서는 다음의 두가지를 유의할 필요가 있다. 첫째, 기금조성의 성과를 평가하는 기준으로는 기금조성의 성공여부(success)와 효과성(effectiveness)을 동시에 할용할 필요가 있다. 성 공여부는 대학이 설정한 일정기간(대체로 단기간)에 목표로 한 금액 대비 실제로 흭독 한 기부금액이 얼마인가에 관심올 두며, 효과성은 주어잔 현실여건 하에서 실제로 흭득 한 기부금액 이외에도 잠재 기부금액에 있어 장기적으로 기금조성이 얼마나 안정적으 로 성장하였는가에 관심을 둔다 (Cook and Lasher 1996). 성공적인 기금조성이란 실제로 모 금한 기부금 규모에 의해 결정되지만, 효과적인 기금조성은 실제로 힉득한 기부금 뿐만 아 니라 잠재기부금도 포함하여 결정된다. Cook and Lasher (1996)는 미국 대학의 CEO에 대한 서 베이 결과, 이들이 기금조성에 많은 관심과 노력울 기울였음에도 불구하고 단기간의 실제 성과는 적은 반면, 적은 관심과 노력을 기울였음에도 불구하고 많은 성과를 올리고 있음을 보고하고 있다.

둘째, 기금조성 활동에 대한 평가는 거시적 측면과 미시적 측면에서 동시에 평가할 필요 가 있다. 기금조성 성과의 평가기준은 크게 대학 차원에서 전반적인 성과를 평가하는 거시 적 평가기준과 개별 기금조성자 혹은 기금조성부서의 성과를 평가하는 미시적 평가기준으로 구분할 수 있다. 거시적 평가기준으로는 시장형태/모금기법/기부금 형태별 목표달성율 
(percentage of goal reached), 평균 기부액, 경쟁대학 대비 시장점유율 (relative market share), 비용/공헌도 (expense/contribution ratio)둥이 활용되고 있다. 미시적 평가기준으로는 기부 자 개발 건 수, 기금요청제안서 작성 건수, 평균 요청액, 중결된 제안 수, 제안 종결율, 종결된 제안의 평균 조성액과 평균 소요비용, 조성기금 단위당 평균 소요비용 등이 활 용된다. 기금조성활동에 투여된 비용을 지속적이고도 체계적으로 수집함으로써 기금조성성 과에 대한 사후분석이 가능해진다 (Lindahl 1992).

본연구에서는 기금조성의 성과변수로 1)실제 모금액과 2)기금조성부서장의 주요 거시평가 기준과 미시평가기준에서의 만족도, 3)전반적인 기금조성할동에 대한 만족도를 활용하고 있 다.

\section{3. 연구방법}

\section{1. 주요 변수}

본 연구에 포함된 주요 변수로는 대학의 1)기금조성 성과, 2)기금조성활동에서의 시장지 향적 접근, 3)기금조성 전략계혁의 체계성,4)기금조성조직의 폭성, 5)기금조성에 대한 몰입, 6) 기타 대학특성 변수로 구분된다.

기금조성 성과는 1)전년도의 실제 모금액과 2)기금조성성과에 대한 만족도를 통해 측정 하고 있다, 기금조성 성과에 대한 만족도는 최근 3년간의 목표모금액 대비 실제모금액, 모 금액 중가율, 기부자 수 증가율, 경쟁대학 대비 모금액, 전반적인 기금조성 성과 등 5 가지 평가기준에 있어 기금조성활동이 얼마나 만족스러운가률 5점 척도('매우 불만족함'(1점)에 서 '매우 만족함'(5점)까지)에 의해 측정하고 있다.

기금조성활동에서의 시장지향적 접근온 시장지향성과 마케팅 조사의 실시여부에 의해 측 정하고 있다. 시장지향성은 Kohli, Jaworski, and Kumar(1993)에 의해 제시된 시장지향성 척도 인 MARKOR의 20개 문항 중 대표적인 문항 5 개를 대학의 기금조성 상황에 맞게끔 수정하 여 5점 동의-비동의 척도에 의해 측정하고 있다. 이들 문항은 MARKOR의 네 가지 하위차 원인 (1)정보창출(예: 우리대학은 현재 및 잠재 기부자가 우리대학으로부터 기대하는 것이 무엇인지를 파악하기 위해 다양한 조사률 실시하고 있다), (2)정보유포 (예: 기금조성부서와 여타 부서간에 기금조성과 관련된 정보교환과 협조가 잘 이루어지고 있다), (3)반응설계 (예: 우리대학온 타대학이 적극적인 기금조성캠페인에 나설 경우, 즉각 이에 상웅하는 캠페 인에 나선다), (4)반웅실행 (예: 우리대학은 기금조성계혁을 적절하게 실행할 수 있는 능력 을 지니고 있다)의 네가지 차원을 반영하고 있다. 마케텅조사의 실시여부는 기금조성캠페 인에 있어서의 사전조사(feasibility tests)의 실시여부와 외부전문가나 컨설팅기업의 활용여부 를 붕해 측정하고 있다.

기금조성 전략계힉의 체계성은 1)장기발전계획의 체계적 수립운용, 2)기금조성계흭과 장 기발전계흭과의 연계성을 퉁해 측정하고 있다. 장기발전계흭의 수립운용은 장기발전계힉 상의 대학사명과 목표의 명문화 정도, 장기발전계혁에 대한 구성원의 공감대 형성정도, 장 기발전계획의 일관된 추진정도률 5 점 리커트 형태의 동의-비동의 척도('전혀 동의하지 않 
음’(1점)에서 ‘전적으로 동의함’(5점)까지)에 의해 측정하고 있다. 장기발전계획과 기금조성 활동간의 연계성은 장기발전계휙상의 기금조성목표의 명시정도, 기부제의에 대한 평가체계 의 엄격성, 기금조성목표에서의 우선순위의 명시정도와 관련된 다섯개의 문항에 대한 5 점 리커트 형태의 동의-비동의 척도에 의해 측정하고 있다.

기금조성조직의 특성은 공식적이고 독립된 부서의 활용여부, 부서장의 직급과 근무 경력, 상근직원의 수와 평균 근무기간, 기금조성 운영위원희(steering committee)의 활용여부, 기금 조성 부서장의 역할 둥을 측정하고 있다. 또한 기금조성부서에 대한 투자는 예산과 인력의 지원 정도를 묻는 주관적 문항에 대한 동의정도를 5 점 리커트 형태의 동의-비동의 척도에 의해 측정하고 있다.

기금조성에의 몰입은 충장의 리더쉅, 재단이사와 보직교수의 관심과 노력정도를 묻는 네 개의 문항과, 대학구성원의 공감대와 참여정도를 묻는 세개의 문항에 대한 동의정도를 5 점 리커트 형태의 동의-비동의 척도에 의해 측정하고 있다.

그밖에 기금조성과 관련된 대학특성변수로는 대학유형, 지리적 위치, 규모(신입생 정원), 대학의 역사, 대학의 사회적 평판에 대한 웅답자의 주관적 평가 둥율 측정하고 있다.

\section{2. 표본 및 자료수집 절차}

본 연구는 대학의 기금조성활동에 대한 평가를 목적으로 하고 있기 때문에 비록 기금조 성부서장을 대상으로 우편설문조사가 이루어지기는 하였으나 분석단위가 대학이라는 점을 염두에 둘 필요가 있다. 본 연구에 이용된 표본온 1998년 현재 전국대학교 기획실(처)장 협 의회에 가입하고 있는 130 개 국내 4년제 국공립 및 사립대학으로, 주 응답자(key informants) 는 전· 현직 기힉실장과 대외협력 부서장으로 한정하였다.

우편설문조사는 설문서를 보내기 일주일 전에 협조편지를 발송하는 것으로부터 시작하였 다. 안내편지에는 연구의 목적과 내용, 협조요청, 익명 통계처리 및 연구결과의 개별통지에 대한 약속 등이 간략히 기술되었다. 최종설문서는 협조편지를 발송한 일주일 후 안내편지 및 회신용 봉투와 함께 발송되었다. 설문서를 발송한 지 열흘에서 2 주일 사이에는 이미 회 수된 표본을 제외한 나머지 대학을 대상으로 웅답 촉구편지가 발송되었다.

최초의 설문서가 발송된 후 약 한 달에 걸쳐 설문서를 보내은 대학은 모두 55 개 대학(옹 답율 $42 \%$ )이며 3 개 대학의 경우에는 웅답을 정중히 거절하거나 자신의 대학은 적절한 대상 이 아넘을 알려왔다. 우편설문조사의 경우 응답률이 대체로 $20 \%$ 내지 $30 \%$ 수준인 점을 감 안한다면 본 연구의 웅답률은 비교적 높은 것으로 평가할 수 있다. 표본 대학의 주요 특성 은 <표 2>에 나타나고 있다. 
<표 2> 표본대학의 주.8. 톡성 $(\mathrm{N}=55)$

\begin{tabular}{|c|c|c|c|}
\hline 대학특성 & 구분/빈도 & 대학특성 & 구분/빈도 \\
\hline 유형 & $\begin{array}{l}\text { 국공립종합대학( 7) } \\
\text { 국공립특수대학 (5) } \\
\text { 사립종합대학(41) } \\
\text { 사립특수대확(2) }\end{array}$ & 전임교수 수 & $\begin{array}{l}100 \text { 명 미만( 7) } \\
100-200 \text { 명 미만(14) } \\
200-300 \text { 명 미만(14) } \\
300-500 \text { 명 미만(6) } \\
\text { 5nn명 이산(14) }\end{array}$ \\
\hline 지역 & $\begin{array}{l}\text { 서울(11) } \\
\text { 수도권(8) } \\
\text { 기타(36) }\end{array}$ & 대학의 역사 & $\left\{\begin{array}{l}10 \text { 년 미만(7) } \\
10 \text { 년-30년 미만(13) } \\
30 \text { 년-50년 미만(12) } \\
50 \text { 년 이상(23) }\end{array}\right.$ \\
\hline 신입생입학정 원 & $\begin{array}{c}1500 \text { 명 미만(12) } \\
1500 \text { 명 이상- } \\
3000 \text { 명 미만(27) } \\
3000 \text { 명 이상(16) }\end{array}$ & 사회적 평만 & $\begin{array}{l}\text { 상위권( } 8) \\
\text { 중위권(44) } \\
\text { 하위권(3) }\end{array}$ \\
\hline
\end{tabular}

\section{4. 분석결과 및 토의}

\section{1. 측정치의 타당성 검토}

본 연구에서 타당성 검토의 대상이 되는 개념은 성과변수 중 기금조성성과에 대한 만족도, 선행변수 중에서는 시장지향성, 장기발전계혁의 수립운용, 기금조성전략과 장기발전계힉간의 연계성, 대학구성원의 몰입, $\mathrm{CEO}$ 의 몰입, 기금조성부서에 대한 투자가 포함된다.

<표 3>은 주요개념의 측정치들에 대한 공통요인분석(common factor analysis) 결과와 신뢰성 분석결과를 보여주고 있다. 모든 측정치는 단일요인에 적재되고 있는 것으로 나타났으며, 이들 개념의 신뢰성 또한 Nunnally(1978)가 제시하는 허용기준(a=0.7)보다 높은 것으로 나 타났다.

\section{2. 기술 통계}

\subsection{1. 기금조성 성과}

55 개 표본대학의 1999년도 평균 기금조성액(수탁연구비와 재단전입금 제외)은 26억 4천 만원인 것으로 나타났다. 그러나 불과 3 개 대학만이 100 억 이상을 조성한 것으로 나타넜으 며 5 억원 미만을 조성한 대학이 전체의 약 $50 \%$ 를 차지하고 있다. 웅답을 거부한 8 개 대학 대부분은 기금조성실적이 미미할 것으로 판단되고 있다.

5 개 문항으로 측정한 기금조성 성과에 대한 만족도는 대체로 낮은 것으로 나타났다 (평 균 $=2.690$. 표준편차 $=993$ ). 웅답자의 대부분은 소속대학의 전반적인 기금조성 성과에 대해 만족하지 않는 것으로 나타넜으며(평균 $=2.809$, 표준편차=1.109), 목표모금액 대비 실제모금 액, 모금액 중가율, 기부자 수 중가율, 경쟁대학 대비 모금액의 네가지 평가기준 중 특히 
경쟁대학 대비 모금액에 있어 불만족이 높은 것으로 나타났다(평균 $=2.384$, 표준편차=1.066).

<표 3> 요인분석 및 신뢰성분석 결과

\begin{tabular}{|c|c|c|c|c|}
\hline \multirow[t]{2}{*}{ 개념/문항 } & \multicolumn{3}{|c|}{ 요인푼석결과 } & \multirow[b]{2}{*}{ Cronbach'sa } \\
\hline & 적재치 & 아이겐값 & 분산비월 & \\
\hline $\begin{array}{c}\text { 기금조성성과에 대한 만족 } \\
\text { SAT1 } \\
\text { SAT2 } \\
\text { SAT3 } \\
\text { SAT5 } \\
\text { SAT4 }\end{array}$ & $\begin{array}{l}.903 \\
.886 \\
.886 \\
.726\end{array}$ & 3.698 & 74.0 & .932 \\
\hline $\begin{array}{l}\text { 지상짛ㅎㅇ엉 } \\
\text { MARK2 } \\
\text { MARK3 } \\
\text { MARK1 } \\
\text { MARK4 } \\
\text { MARK5 }\end{array}$ & $\begin{array}{l}.895 \\
.784 \\
.757 \\
.529 \\
.440\end{array}$ & 2.461 & 49.2 & .809 \\
\hline 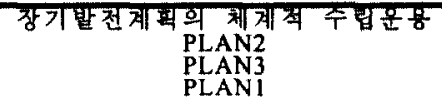 & $\begin{array}{r}.907 \\
.782 \\
.732\end{array}$ & 1.971 & 65.7 & .736 \\
\hline $\begin{array}{c}\text { 기금조성전박가 장가발전계락 과의 } \\
\text { 연 계성 } \\
\text { TIE3 } \\
\text { TIE2 } \\
\text { TIES } \\
\text { TIE1 } \\
\text { TIE4 }\end{array}$ & 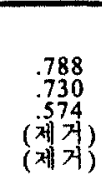 & 1.485 & 49.5 & .729 \\
\hline $\begin{array}{l}\text { CEO } 9 \text { 늘업 } \\
\text { CMTC2 } \\
\text { CMTC1 } \\
\text { CMTC4 } \\
\text { CMTC3 }\end{array}$ & $\begin{array}{l}.894 \\
.698 \\
.601 \\
.463\end{array}$ & 1.862 & 46.6 & .751 \\
\hline $\begin{array}{c}\text { 대학구성원의 늘입 } \\
\text { CMTS3 } \\
\text { CMTS1 } \\
\text { CMTS2 }\end{array}$ & $\begin{array}{l}.887 \\
.739 \\
.732\end{array}$ & 1.860 & 62.3 & .823 \\
\hline $\begin{array}{c}\text { 기금조성부서에 대한 후자 } \\
\text { INV2 } \\
\text { INV1 }\end{array}$ & $\begin{array}{l}.750 \\
.750\end{array}$ & 1.125 & 56.2 & .719 \\
\hline
\end{tabular}

\subsection{2, 시장지향성과 마케팅 조사}

표본대학의 기금조성활동에서의 시장지향성은 비교적 낮은 것으로 나타넜다(평균 $=2.727$, 표준편차=.748). 시장지향성의 네가지 차원 중 특히 정보창출(기부자의 기대파악과 추세파 악)과 반옹설계(경쟁대학에 상응하는 적극적인 캠페인)에서의 활둥이 미흡한 것으로 나타났 다.

한편 기금조성과 관련된 마케텅 조사 역시 매우 미약한 것으로 나타나고 있다. 절대 다수 의 대학이 기금조성 가능성에 대한 공식적인 사전조사나 외부전문가, 컨설팅 기업을 활용 하고 있지 않은 것으로 나타넜다. 가능성 조사를 실시하는 대학과 전문컨설턴트를 활용하 고 있는 대학은 각각 4 개 대학과 3 개 대학인 것으로 나타났다.

\subsection{3. 기금조성 전략계획의 체계성}

장기발전계획의 체계적 수립운영: 표본대학은 나름대로 장기발전계획올 체계적으로 수립 하여 운용하고 있는 것으로 나타났다(평 균 $=3.651$, 표준편차= $=749$ ). 표본대학의 상당수가 장기 발전계힉에 해당 대학의 사명과 목표를 명확하게 제시하고 있고 (평균 $=4.046$, 표준면차 $=.785$ ), 장기발전계획에 대해 구성원간에 공감대가 형성되어 있으며(평균 $=3.511$, 표준편차 =984), 오랫동안 장기발전계획을 일관되게 추진하고 있는 것으로 웅답하고 있다(평균=3.395, 
표준편차=.979).

기금조성전랴ㄱㅘㅘ 장기발전계흭퐈의 연계성: 표본대학의 기금조성전략과 장기발전계흭간의 연계성은 그다지 높지 않은 것으로 나타나고 있다(평균 $=2.942$, 표준편차=.772). 특히 장기발 전계획에 기금조성목표가 분명하게 제시되어 있지 않으며(평균=2.744, 표준편차=1.115), 기부 제의에 대한 평가체계가 미홉한 것으로 나타났다(평균 $=2.744$, 표준편차=1.026). 참고로 표본 대학은 동문을 대상으로 한 간청(71\%)과 교수, 직원을 대상으로 한 단기 캠페인(67\%)을 주 된 기금조성전략으로 할용하고 있는 것으로 나타넜다. 그러나 부유충을 대상으로 한 간청 $(21 \%)$ 이나 지역사회에 대한 간청 $(29 \%)$ 은 대체로 실시하고 있지 않은 것으로 나타났다.

\subsection{4. 기금조성조직}

표본대학의 $64 \%$ 가 대외협력처(실), 기흭처 둥 기금조성을 공식적으로 책임지고 있는 독 립부서를 지니고 있는 것으로 나타났다. 강식조직의 명칭은 대외협력처, 기휙훙보처, 기흭 연구실, 발전캠페인 본부, 기흭담당관실, 마케팅처 둥 다양한 명칭이 할용되고 있는 것으로 나타났다. 부서장의 직위도 계장으로부터 부총장에 이르기까지 다양한 것으로 나타났다. 부 서장의 역할에 대해서는 촉매자(38.3\%), 관리자(36.2\%), 판매원(8.5\%), 선도자(8.5\%)의 순으로 빈도가 높은 것으로 나타났다. 즉, 대부분의 기금조성 부서장은 자신의 역할을 총장과 여타 부서장에 대한 후방지원이나 기금조성 전략계혁의 수립과 인력관리로 인식하고 있는 반면, 적극적인 모금자나 중요정책결정과정에의 참여자로서의 인식은 낮은 것으로 나타넜다.

부서장을 포함한 상근 직원의 수는 3 명, 부서장과 상근직원의 기금조성부서에서의 평균 근무기간은 각각 27 개월과 33 개월인 것으로 나타났다. 기금조성부서의 일년 예산은 평균 2 억 8천만원인 것으로 나타났으며, 절반에 가까운 대학이 1 억 이하의 예산으로 운영되는 것 으로 나타넜다. 기금조성부서에 대한 투자와 관련하여 표본대학온 대체로 예산과 인력이 충분하지 못한 것으로 웅답하고 있다(평균 $=2.426$, 표준편차 $=.824$ )

\subsection{5. 기금조성에의 몰입}

기금조성활동에 있어 총장, 재단이사 및 보직교수의 리더웝은 대체로 낮은 것으로 나타 넜다(평균 $=2.806$, 표준편차=.699). 반면 기금조성의 필요성에 대한 대학구성원의 공감대 형 성정도와 참여정도는 비교적 높은 것으로 나타나고 있다(평균 $=3.341$, 표준편차 $=.851$ ).

\section{3. 기금조성성과와 여타변수와의 관계}

\subsection{1. 상 관분석}

<표 4>는 기금조성성과에 영향을 미칠 것으로 판단되는 다섯 가지의 선행변수와 기금조 성 성과와의 관계률 단순상관분석과 일원분산분석(One-way ANOVA) 결과에 의해 보여주고 있다. 여기서 보면, 실제 모금액과 기금조성성과에 대한 만족도와 유의적인 관련을 맺고 있는 선행변수는 시장지향적 접근, 전략계핵의 체계성, 대학규모, 대학에 대한 사희적 평판 등인 것으로 나타나고 있다. 
<표 4> 기금조성 성과와 선행변수와의 관계

\begin{tabular}{|c|c|c|c|c|c|}
\hline \multirow[b]{2}{*}{ 선행변수 } & \multirow[b]{2}{*}{ 하위차원 } & \multicolumn{2}{|c|}{ 실제 모금액 } & \multicolumn{2}{|c|}{ 성과에 대한 만족 } \\
\hline & & $\begin{array}{l}\text { 상관계수 } \\
\text { (*는 F값) }\end{array}$ & $\mathrm{p}$ & $\begin{array}{c}\text { 상관계수 } \\
\text { (*는 F값) }\end{array}$ & $\mathrm{p}$ \\
\hline \multirow{3}{*}{$\begin{array}{l}\text { 시장지향적 } \\
\text { 접근 }\end{array}$} & 시장지향성 & .447 & .002 & .601 & .000 \\
\hline & 가능성조사 실시여부 & .607 & .000 & .248 & .093 \\
\hline & 전문컨설턴트 활용여부 & .616 & .000 & .501 & .000 \\
\hline \multirow{2}{*}{$\begin{array}{l}\text { 전략계힉의 } \\
\text { 체계성 }\end{array}$} & $\begin{array}{l}\text { 장기발전계혁의 체계적 } \\
\text { 수립운용 }\end{array}$ & .223 & .136 & .350 & .016 \\
\hline & $\begin{array}{l}\text { 기금조성전략과 장기발전계 } \\
\text { 힉의 연계성 }\end{array}$ & .371 & .011 & .353 & .015 \\
\hline \multirow{8}{*}{$\begin{array}{l}\text { 기금조성 } \\
\text { 조직 }\end{array}$} & 독립된 부서의 존재여부 & .213 & .155 & .076 & .611 \\
\hline & 기금조성부서에 대한 투자 & .500 & .000 & .496 & .000 \\
\hline & 부서장의 직위 & $2.052^{*}$ & .073 & $.526^{*}$ & .808 \\
\hline & 부서장의 경력 & -.018 & .912 & .116 & .489 \\
\hline & 부서장의 역할 & $.528 *$ & .665 & $.245^{*}$ & .865 \\
\hline & 스탭의 수 & .031 & .853 & .117 & .486 \\
\hline & 스탭의 경력 & .031 & .855 & .192 & .263 \\
\hline & 운영위원회 활용여부 & .069 & .658 & .040 & .797 \\
\hline \multirow{2}{*}{$\begin{array}{l}\text { 기금조성에 } \\
\text { 의 몰입 }\end{array}$} & $\begin{array}{l}\text { 총장/재단이사/보직교수의 } \\
\text { 몰입 }\end{array}$ & .307 & .042 & .532 & .000 \\
\hline & 대학구성원의 몰입 & .439 & .003 & .537 & .000 \\
\hline \multirow{5}{*}{$\begin{array}{c}\text { 기타 } \\
\text { 배경특성 }\end{array}$} & 유형 & $.506^{*}$ & .646 & $.472 *$ & .705 \\
\hline & 규모(학생수) & .357 & .015 & .227 & .125 \\
\hline & 역사 & .150 & .320 & .269 & .068 \\
\hline & 사화적 평판 & .356 & .015 & .225 & .129 \\
\hline & 지역 & $1.218^{*}$ & .306 & $.042 *$ & .959 \\
\hline
\end{tabular}

보다 구체적으로 실제 모금액은 1)대학이 시장지향적이고, 사전 가능성 조사와 전문컨설 턴트를 활용하고 있을수록, 2)기금조성전략과 장기발전계획이 연계되어 있을수록, 3)기금조성 예산과 인력 등 기금조성활동에 대한 트자가 많을수록, 4)총장, 재단이사를 포함한 대학구성 원의 몰입수준이 높을수록, 5)대학의 규모가 크고 사회적 평판이 높을수록 높은 것으로 나타 나고 있다.

기금조성 성과에 대한 만족도는 1)대학이 시장지향적이고 전문킨설턴트를 할용하고 있을 수록, 2)장기발전계힉을 체계적으로 수립하고 있고 기금조성전략이 이와 연계되어 있을수록, 3)기금조성부서에 대한 투자가 많을수록, 4)충장, 재단이사를 포함한 대학구성원의 몰입정도 가 높을수록 높은 것으로 나타나고 있다.

상관분석결과를 퉁해 드러난 두드러진 특징은 시장지향적 접근, 기금조성전략과 장기발 전계획간의 연계성, 대학구성원의 몰입수준이 실제 모금액과 만족도에 모두 유의적인 관련 을 맺고 있는 반면에, 대부분의 기금조성조직 관련 하위차원은 기금조성 성과와 유의적인 관련을 맺고 있지 않다는 점이다.

기금조성조직의 하위차원들이 기금조성 성과와 대체로 무관한 것으로 나타난 것은 첫째, 
현실적으로 대학에 대한 기부가 기금조성조직과는 상관없이 개인적인 친분관계나 대학에 대 한 사희적 평판에 의해 이루어지고 있고 둘째, 대부분의 국내대학의 기금조성활동의 중요성 에 대한 인식이 부족하여 기금조성조직이 아직 체계화되어 있지 못하고 이들 대학간의 변이 (variation)가 적다는 것으로 설명이 가능하다.

\subsection{2. 회귀분석}

상관분석 결과 유의적인 것으로 나타난 선행변수들에 의해 전년도의 실제 모금액과 만족 도를 종속변수로 하는 회귀분석을 실시한 결과, 거의 모든 선행변수들의 고유효과가 유의수 준 0.05 에서 툼계적으로 유의적이지 않은 것으로 나타나고 있다(<표 $5>$ 참조). 실제모금액 의 경우에는 모든 선행변수가 유의수준 0.05 수준에서 퉁계적으로 유의적이지 않은 것으로

나타넜다. 단지 사전가능성 조사의 실시여부와 전문컨설턴트의 활용여부만이 유의수준 0.10 에서 유의적인 것으로 나타나고 있다. 기금조성 성과에 대한 만족도의 경우에는 실제 모금 액이 많고 시장지향성이 높을수록 만족도가 중가하는 것으로 나타났으며 나머지 변수는 모 두 비유의적인 것으로 나타넜다.

<표 $5>$ 회귀분석 결과

\begin{tabular}{|c|c|c|c|c|}
\hline \multirow{3}{*}{ 선행변수 } & \multicolumn{4}{|c|}{ 종속변수 } \\
\hline & \multicolumn{2}{|c|}{$\begin{array}{l}\text { 전년도 실제 } \\
\text { 모금액 }\end{array}$} & \multicolumn{2}{|c|}{$\begin{array}{l}\text { 성과에 대한 } \\
\text { 만족도 }\end{array}$} \\
\hline & beta & $t$ & beta & $t$ \\
\hline 저녀두 식제 므극액 & - & $=$ & 375 & 7.401 \\
\hline 시장지향성 & .358 & 1.354 & .611 & 2.435 \\
\hline 가눙성 조사 실시여부 & .309 & 1.934 & - & - \\
\hline 전문컨설턴트 할용여부 & .306 & 1.936 & .162 & 1.085 \\
\hline 장기발전계혁의 체계적 수립운용 & - & - & .014 & .089 \\
\hline $\begin{array}{l}\text { 기금조성전략과 장기발전계혁으 } \\
\text { 연계성 }\end{array}$ & -.086 & -.517 & -.149 & -.922 \\
\hline 기금조성부서에 대한 투자 & .048 & .269 & -.117 & -.665 \\
\hline 총장, 재단이사, 보직교수의 몰입 & -.292 & -1.643 & .098 & .568 \\
\hline 대학구성 원의 물입 & .092 & .449 & -.059 & -.302 \\
\hline 규모(학생수) & .096 & .705 & - & - \\
\hline 사회적 평판 & .249 & 1.767 & - & - \\
\hline $\mathbf{R}^{2}$ & \multicolumn{2}{|c|}{.618} & \multicolumn{2}{|c|}{.658} \\
\hline$F(d f)$ & \multicolumn{2}{|c|}{$5.740(9,32)$} & \multicolumn{2}{|c|}{$7.469(8,31)$} \\
\hline$p$ & \multicolumn{2}{|c|}{.000} & \multicolumn{2}{|c|}{.000} \\
\hline 표본수 & \multicolumn{2}{|c|}{42} & \multicolumn{2}{|c|}{40} \\
\hline
\end{tabular}

대부분의 선행변수와 기금조성성과와의 단순상관계수가 유의적이고 모형의 설명력이 매우 높음에도 불구하고 이러한 결과가 나타난 것은, 무웅답을 제거한 결과 표본의 수가 너무 적 어졌다는데도 원인이 있지만, 무엇보다 다중공선성, 즉 선행변수들간의 상관관계가 매우 높 은 데 원인이 있는 것으로 뷸 수 있다. (선행변수간의 상관계수는 <표 6>을 참조.) 
<표 6> 선행변수간의 상관관계

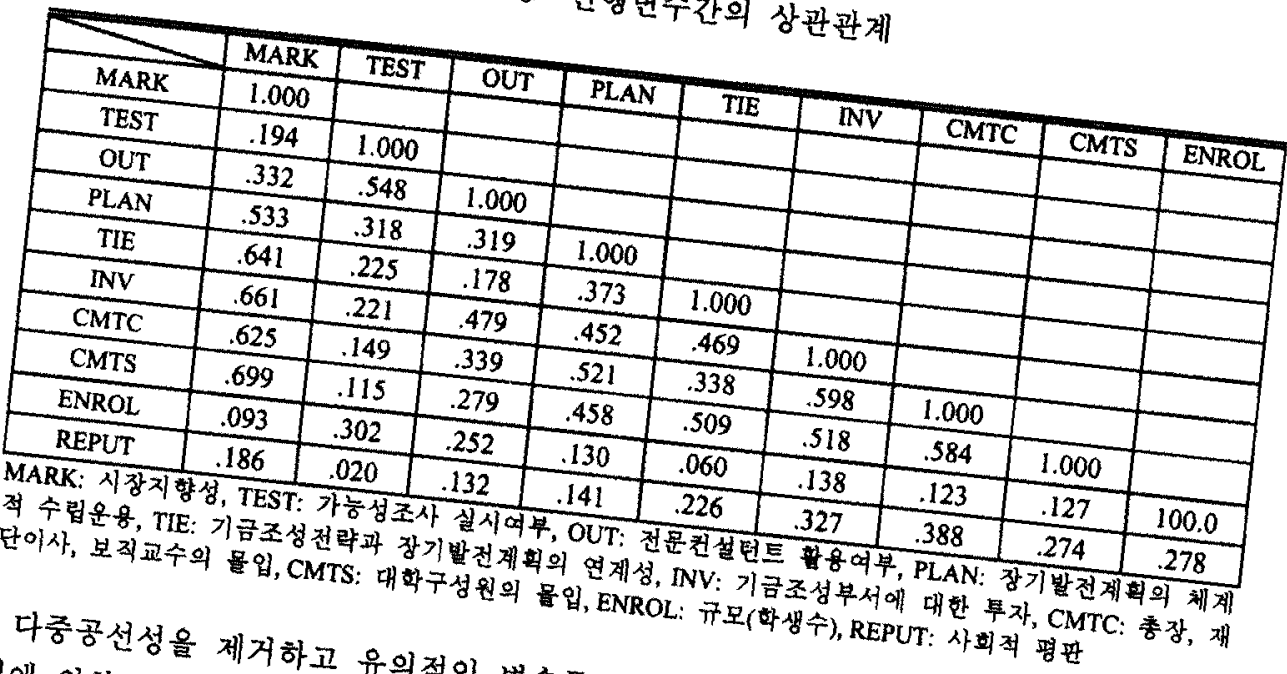

입에 의한 희기베거하고 유의적인 변수를 찾기 위한 방안

설턴트 활용여분석(stepwise regression) 결과를 보면, 전년도의 하나로 선행변수의 단계적 투 $t=2.066)$ 이 유의적인 $=480, \quad t=3.972)$, 규모(beta $=.260, \quad t=2.228$, 실제 모금액의 경우에는 전문컨 도의 경우에는 시장지항항을 미치는 것으로 나타났으며 $\left(\mathrm{R}^{2}=5\right)$, 대학구성원의 몰입(beta=247, 향을 미치는 것으로 나타낭다 $\left(R^{2}=494, t=4.289\right)$ 과 전년도 실제 모 $\left.F(3,38)=13.797, p=.000\right)$, 만족

<그림 2>기금조성 성과모형

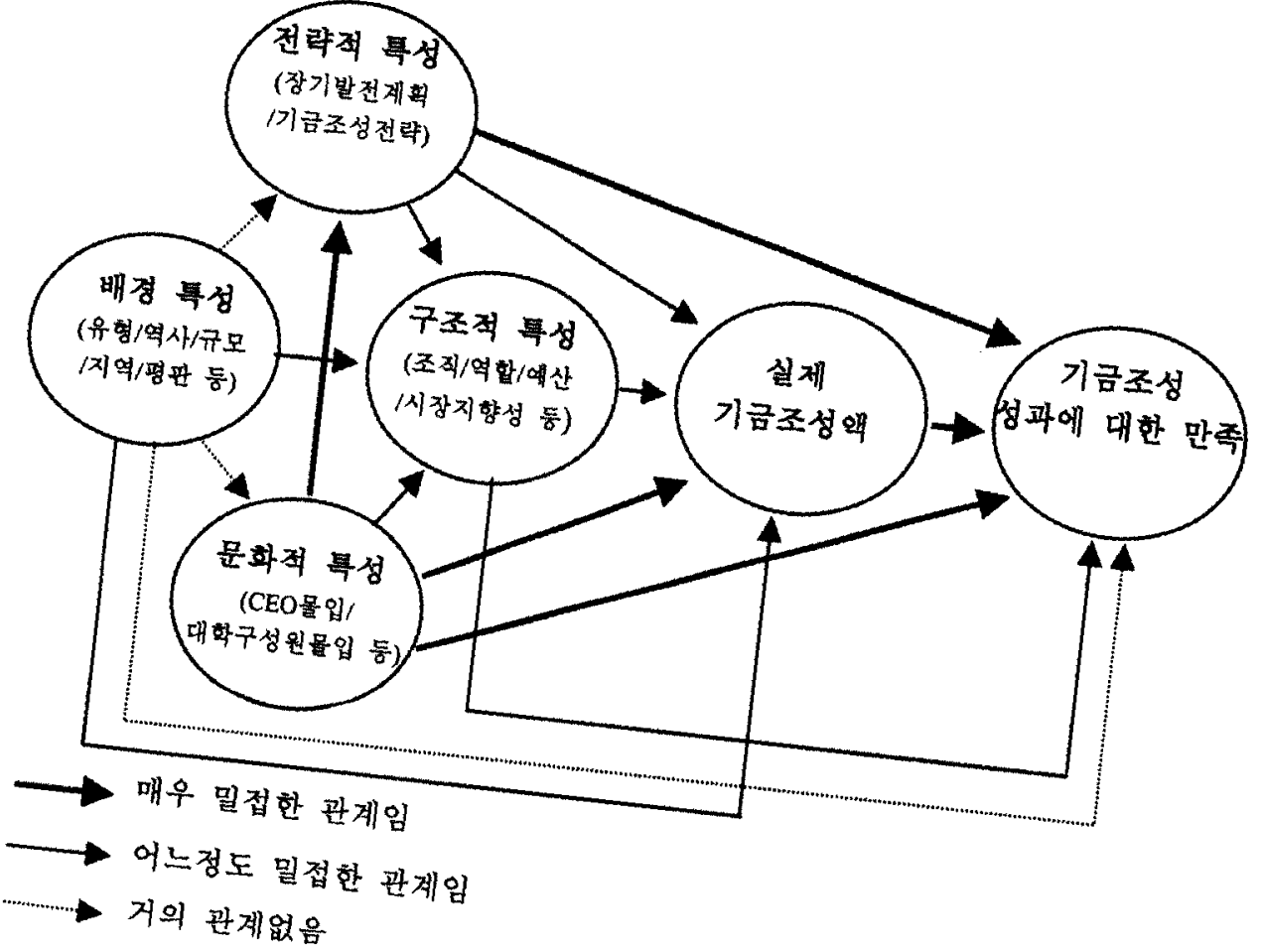




\subsection{3. 기금조성 성과모형의 제시}

앞서의 회귀분석 결과는 선행변수간의 상관관계가 높아 개별 선행변수의 고유설명력이 통 계적으로 유의적이지 않옴올 보여주고 있다. 따라서 선행변수간의 인과 관계를 이론적으로 규명합으로써 다중공선성의 문제를 이론적으로 해결하고 기금조성 성과모형을 보다 정교화 할 필요가 있다. <그림 2>는 선행변수간의 상관관계분석과 앞서의 회귀분석졀과를 통해 나 타난 결과를 토대로 기금조성 성과모형을 구성한 것이다. 이를 설명하면 다음과 같다.

본 연구에서의 선행변수는 크게 대학의 구조적 특성, 전략적 특성, 문화적 특성, 기타 배 경(contextual) 특성으로 구분할 수 있다. 대학의 역사, 규모, 사회적 평판 둥의 배경 특성은 대체로 대학이 퉁제불가능하거나 장기간에 걸쳐 형성되는 것이기에 구조와 문화, 전략을 결 정짓는 선행변수로 볼 수 있으며, 문화적 특성온 지속적인 특정을 지니므로 기금조성 조직 구조나 전략의 선행변수라 할 수 있다. 조직구조와 전략 중 무엇이 선행변수인가에 대하여 는 논란이 있을 수 있으나 대체로 전략계획수립과정에서는 전략이 우선 결정되고 이에 의해 구조가 결정되는 것으로 보고 있다. 한편 본 연구에서는 구조적 톡성으로 기금조성조직의 설계 및 운영과 관련된 변수 이외에도 시장지향적 접근방식의 세가지 변수(시장지향성, 가 능성조사의 실시여부, 전문컨설턴트의 활용여부)를 포함시키고 있다. 이는 시장지향적 접근 의 하위차원들이 주로 정보의 입수와 배포, 활용 구조와 관련올 맺고 있기 때문이다. 구조, 전략, 문화, 기타 배경특성 간의 상관관계 분석 결과 나타난 주요 특징을 기술하면 다음과 같다.

첫째, 대학의 배경 특성변수인 규모나 역사, 사회적 평판은 여타 특성변수와 대체로 무관 한 것으로 나타나고 있다(유의수준=.05). 단지, 사회적 평판이 높은 대학일수록 총장, 재단이 사, 보직교수 $(\mathrm{r}=.388, \mathrm{p}=.005)$ 와 대학구성원 $(\mathrm{r}=.274, \mathrm{p}=.047)$ 의 기금조성에의 몰입수준이 높고, 독립된 기금조성부서를 지니고 있으며( $\mathrm{r}=.327, \mathrm{p}=.017)$, 기금조성부서에 대한 투자가 많은 것 으로 나타났다 $(\mathrm{r}=.327, \mathrm{p}=.017)$. 또한 규모가 큰 대학일수록 사전가능성조사를 실시하고 $(\mathrm{r}=.302$, $\mathrm{p}=030)$, 독립된 기금조성부서를 지니고 있으며 $(\mathrm{r}=.436, \mathrm{p}=.001)$, 스탭의 기금조성부서 경력이 높은 것으로 나타났다 $(\mathrm{r}=.335, \mathrm{p}=.033)$.

둘째, 대학의 문화적 톡성은 전략적 특성과 매우 밀접한 관련을 맺는 것으로 나타났다. 대 학의 $\mathrm{CEO}$ 의 몰입수준이 높을수록 장기발전계획이 체계적으로 수립. 운영되고 있고 $\mathrm{r}=.521$, $\mathrm{p}=.000)$, 기금조성전략과 장기발전계힉간의 연계성도 높은 것으로 나타났다 $(\mathrm{r}=.338, \mathrm{p}=.016)$. 또한 교수, 직원, 학생 둥 대학 구성원의 몰입수준이 높을수록 장기발전계힉이 체계적으로 수립· 운영되고 있고( $\mathrm{r}=.458, \mathrm{p}=.001)$, 기금조성전략과 장기발전계획간의 연계성도 높은 것으 로 나타났다(r=.509, $\mathrm{p}=.000)$. 이는 총장이나 재단이사 둥 $\mathrm{CEO}$ 의 몰입도 중요하지만 대학구성 원의 몰입 또한 기금조성전략의 수립, 실행, 통제에 있어 매우 중요함을 암시하고 있다. 문 화적 특성은 일부 구조적 특성과도 관련을 맺는 것으로 나타나고 있는 바, $\mathrm{CEO}$ 의 몰입수준 이 높을수록 독립된 기금조성부서를 지니고 있으며( $\mathrm{r}=.418, \mathrm{p}=.002), \mathrm{CEO}$ 의 몰입수준이 높을 수록( $\mathrm{r}=.598, \mathrm{p}=.000)$ 또한 대학구성원의 몰입수준이 높을수록( $\mathrm{r}=.518, \mathrm{p}=.000)$ 기금조성부서에 대한 투자가 많은 것으로 나타났다.

마지막으로 전략적 특성은 구조적 톡성 중 시장지향성 및 기금조성부서에 대한 투자와 매 우 밀접한 관련을 맺고 있는 것으로 나타났다. 장기발전계힉을 체계적으로 수립운용하고 있고( $\mathrm{r}=.452, \mathrm{p}=.001)$, 기금조성전략과 장기발전계흭이 잘 연계되어 있을 수록( $\mathrm{r}=.469, \mathrm{p}=.000)$, 
기금조성부서에 대한 투자가 빦은 것으로 나타넜다. 시장지향성, 즉 기금조성 관련 정보의 입수, 배포, 활용 역시 장기발전계힉이 체계적으로 수립운용되고 있율수록( $\mathrm{r}=.533, \mathrm{p}=.000)$ 또 한 기금조성전략과 장기발전계학이 연계되어 있을수록 $(r=.641, \mathrm{p}=.000)$ 높은 것으로 나타났 다. 그밖에 장기발전계획이 체계적으로 수립. 운용되고 있을수록 가능성 조사를 실시하고 $(\mathrm{r}=.318, \mathrm{p}=.023)$ 전문컨설턴트률 활용하는 것으로 나타났으며 $\mathrm{r}=.319, \mathrm{p}=.021)$, 기금조성전략과 장기발전계획간의 연계성이 높을수록 독립된 기금조성부서와( $=.317, \mathrm{p}=.021)$ 기금조성 운영 위원회 $(\mathrm{r}=.385, \mathrm{p}=.006)$ 률 두고 있는 것으로 나타났다.

\section{5. 결론 및 제언}

본 연구를 퉁해 밝혀진 국내 4년제 대학의 기금조성 전략에 대한 분석결과를 요약하 면 다음과 같다.

첫째, 국내 대학의 기금조성활동은 대체로 도입기에 있다고 할 수 있다. 표본대학의 1999년도 실제 기금조성액은 매우 저조한 것으로 나타나고 있으며 기금조성 성과에 대 한 만족도 역시 낮은 것으로 나타나고 있다. 대다수의 대학이 비록 장기발전계흭을 체 계적으로 수립· 운용하고는 있으나, 장기발전계획과 기금조성 전략과의 연계성은 그다 지 높지않은 것으로 나타나고 있다. 특히 지극히 제한된 수의 기금조성 전략을 구사하 고 있으며, 기금조성 성과에 대한 평가가 전혀 이루어지고 있지 않는 것으로 나타나고 있다. 일부 대학의 경우에는 적극적으로 기금조성할동을 수행하고 있지만 아직도 상당 수의 대학은 기금조성의 중요성을 인식하고 있지 않을 뿐더러 필요한 조직과 전략을 지니고 있지 못한 것으로 나타났다. 기금조성부서의 중요성에 대한 인식이 낮은 결과, 독립된 부서를 지니고 있지 못한 대학이 다수이며, 예산과 인력에 대한 투자가 빈약한 것으로 드러나고 있다.

둘째, 기금조성이 효과적으로 이루어지기 위해서는 마케팅 관점에서의 접근이 중요하 다. 마케팅 관점에서의 접근은 1)시장지향적 접근, 2)체계적 기금조성 전략계흭의 수립, 3)전략실행을 위한 효과적인 조직구조의 설계와 운영, 4)마케팅노력의 퉇합을 가능하게 해주는 핵심요소로 대황의 $\mathrm{CEO}$ 와 구성원의 몰입올 필요로 한다. 본 연구는 실중분석을 통해 이들 변수, 특히 체계적인 장기전략계휙의 수립과 기금조성에의 몰입이 기금조성 성과와 매우 밀접한 관련을 맺고 있음을 확인하고 있다.

셋째, 기금조성관련 문헌은 총장, 재단이사 둥 $\mathrm{CEO}$ 가 기금조성에 있어 핵심적인 역 할을 수행하고 있음을 밝히고 있다. 본 연구에서도 CEO의 몰입이 여타 변수와 밀접한 관련올 맺고 있음을 확인하고 있다. 그러나 본 연구는 $\mathrm{CEO}$ 의 몰입도 중요하지만 대학 구성원의 몰입 역시 광범위하게 기금조성 관련변수에 영향을 미치고 있음을 보여주고 있다. 이와 관련하여 본연구는 기금조성활동에 있어 총장, 재단이사 및 보직교수의 리 더눱은 비교적 낮은 반면, 대학구성원의 믈입수준은 비교적 높다는 점을 확인하고 있다 이는 아직 우리나라의 경우 기금조성능력이 총장이나 보직교수의 선임에 있어 중요하 게 고려되고 있지 않고 오히려 학문적 명성이나 인격, 행정경헙 등이 중요하게 고려되 고 있는 현실을 반영하는 것이라 할 수 있다.

대학구성원의 몰입이 기금조성관련 변수에 광범위한 영향을 미치는 것으로 나타난 
것은 이들이 중요한 기부자 시장인 동시에 전략수행의 주체가 되고 있고, 국내 대학의 기금조성전략이 주로 동문 혹은 교수와 직원을 대상으로 한 단기캠페인에 의존하고 있 으며, 대부분의 대학의 경우 장기발전계획의 수립에 있어 학내 구성원의 공감대 형성이 중요하게 고려되고 있기 때문이라 할 수 있다.

마지막으로, 대학의 배경 특성 중 유형(예를들어 국공립대학 vs. 사립대)이나 역사, 지리적 위치가 기금조성 관련변수 특히 기금조성성과(실제 모금액과 만족도)와는 무관 함을 밝히고 있다. 단지 규모가 큰 대학과 사희적 평판이 높은 대학일수록 실제 모금 액이 높온 것으로 나타나고 있다. 기금조성이 부족한 재정을 확보하는데 기여하는 것이 라 할 때, 본 뗜구는 국내 사립대, 특히 재정상태가 악화되고 있는 소규모 지방대학의 경우 보다 적극적인 기금조성노력이 필요함율 암시하고 있다.

본 연구는 다옴과 같은 점에서 그 의의를 찾을 수 있다. 첫쩨, 대학간의 경쟁이 치열 해지고 있는 국내 고둥교육시장의 변화에 대학이 눙동적으로 대웅함에 있어 가장 시급 한 과제는 재원확보라고 할 수 있다. 본 연구는 기금조성 성과와 선행변수간의 관계를 실중분석을 통해 밝힙으로써 기금조성할동에서의 성과를 높이기 위한 방안을 암시하고 있다. 국내 대학의 기금조성 성과가 미홉한 것은 대학의 사희적 기능에 대한 기업과 일반 대중의 인식부족과 정부의 조세정책 상의 배려가 부족한 것도 이유가 되지만, 기 금조성목표의 설정에서부터 성과에 대한 평가에 이르기까지 많은 대학이 단기적이고 근시안적인 안목과 전술에 의존하고 있다는 점을 들지 않을 수 없다. 각 대학은 추상 적이고 천편일률적이며 유사한 성격의 기금조성활동을 탈피하여 전략적 차원에서 기금 조성 활동을 계흭. 관리하고자 하는 노력을 기울여야 할 것으로 판단된다.

둘째, 본 연구에서 문헌연구의 대상이 되고 있는 미국의 대학들은 이미 20 년 전부터 치열한 경쟁에서 살아남기 위해 다양한 기금조성전략을 구사하고 있으며, 따라서 이들 대학의 경험은 국내 대학의 기금조성전략 수립에 많은 교훈을 줄 수 있올 것으로 기대 된다. 기금조성활동을 포함하여 대학경영에서 마케팅 관점에서의 접근이 지니고 있는 유용성은 이미 미국 대학의 경험을 통해 확인되고 있으며, 이는 경쟁체제에 익숙하지 못한 국내 대학경영에 있어 하나의 혁신적 시도로 수용둴 수 있다.

셋째, 본 연구는 대학의 기금조성활동을 마케팅 관점에서 접근하고 있다. 마케팅 관 점의 핵심은 기부자와 이의 수혜자인 대학간의 교환이 쌍방의 만족올 중요시한다. 기금 조성을 위한 전략계휙의 궁극적인 목표가 대학의 장. 단기 목표의 성취에 있다고 할 때, 체계적인 기금조성은 궁극적으로 교육서비스의 수혜자인 학생과 사회의 발전에 기 여할 수 있는 것으로 기대된다.

마지막으로 정부의 대학에 대한 재정지원이 열악하고 그 동안 기금조성실적이 미흡 한 현실에서 본 연구는 기금조성을 위한 대학의 자구적 노력을 체계화하고 성과를 제 고하는 데 기여할 것으로 기대된다.

본 연구는 기금조성과 관련된 이른과 사례가 체계적으로 정립되어 있지 않은 국내 대학의 기금조성활동을 마케팅 관점에서 평가하고 있는 최초의 의미있는 연구라 할 수 있다. 그럼 에도 불구하고 본 연구는 다음과 같은 한계률 가지고 있다.

첫째, 본 연구는 마케팅 관점에서 대학의 기금조성전략을 평가하는 것을 목적으로 하고 있다. 마케팅 관점에서 볼 때, 기금조성전략에 대한 평가는 대학과 기부자간에 어떤 가치의 
교환이 이루어지는가를 이해하고 있올 때 보다 의미있는 것이 된다. 향후 연구에서는 대학 과 기부자 쌍방을 분석단위로 이들 간에 어떠한 가치의 교환이 이루어지는가를 기부자의 기 부둥기와 관련된 이론적 모형의 제시와 실중분석을 통해 밝힐 필요가 있다. 미국의 경우 1970년대 이후로 기금조성관련 연구에서는 기부자의 기부 행위에 대한 연구가 주를 이 루고 있다(Brittingham and Pezzullo 1990). 예룰들어 Mueth and Newman(1992)은 미국의 368 개 기업을 대상으로 이들 기업의 대학에 대한 기부태도를 조사한 결과, 기업은 전국규 모의 연구중심 박사과정개설 대학에 대해서는 자신의 사업적 이해관계에 의해 기부를 하며, 사립대학에 대해서는 이타주의와 사회적 책임에 근거하여 기부행위를 하는 것으 로 보고하고 있다.

둘째, 본 연구에서는 기금조성 관련부서장(주로 기힉실(처)장과 대외협력처장)을 대상으로 설문조사를 통해 자료를 수집하고 있다. 비록 설문조사의 웅답률과 웅답 내용의 성실성은 비교적 높은 것으로 나타나고 있으나, 표본집단의 수가 적음으로 인해 회귀분석에서의 추정 계수의 안정성(stability)이 크게 위협발을 가능성이 있다. 예를 들어 가능성 조사는 소수의 표본만이 이를 실시하는 것으로 나타나고 있어 성과변수를 종속변수로 하는 회귀식의 추정 계수가 표본크기가 변화하는 경우 크게 변화할 가능성이 높다. 향후 분석에서는 보다 많은 표본을 대상으로 자료를 수집할 필요가 있다.

셋째, 본 연구는 기금조성 성과에 영향을 미칠 것으로 기대되는 선행변수간의 인과관계를 상관관계분석을 통해 귀납적으로 제시하고 있다. 경험적인 것으로부터 이론을 도출하는 것 이 잘못된 것은 아니나, 선행변수간의 관계는 조직이론분야나 마케팅 분야의 기존연구를 통 해 보다 이론적으로 체계화할 필요가 있으며, 이들 간의 관계를 가설형태로 제시하고 검중 할 필요가 있다.

마지막으로 최근의 쟁점으로는 기금조성과정, 톡히 계획된 기부(planned giving)에서의 윤리 적 문제를 들 수 있다 (Ryan 1989; Thompson 1992). 기금조성자는 대학의 이해관계와 기부자 의 이해관계를 동시에 고려하여야 하며, 양자가 상충하는 경우에는 기부자의 이해관계를 우 선적으로 고려하여야 한다. 또한 기부자가 개인적으로 기금조성자에게 기부하고자 하는 경 우 대학이 기금조성자와 기부자에 대한 배려틀 어떻게 할 것인가와 관련하여 대학의 정책을 사전에 분명히 설정할 필요가 있다. 향후 연구에서는 대학과 기금조성자(특히 기금조성 전 문가(development professionals), 기부자, 나아가 기부자의 재산관리인이나 법률자문가와의 관 계에서 발생가능한 윤리적 문제와 이의 해결방안을 연구할 필요가 있다. 


\section{<참고문헌>}

방명숙 (1998), 대학의 기부금 유치기법, 한국고둥교육연수원, 자료 AD-98-16-154.

(1994), “대학의 기부금 현황: 한국과 미국을 중심으로," 교욕정책연구희 발표논

문.

(1995), “기부금 유치방안: 국내 대학의 국제 경쟁력 강화를 위해," 경회대학교

교육문제 연구소 논문집, 제11집, 19-36.

이종훈(1999), "대학재정, 무엇이 문제인가“ 제2희 고등교육정책포럼 기조강연, 한국대학 교욕협의회.

임영균(1996), “전환기의 대학경영 - 사고, 전략, 구조의 혁신," 기업졍영연구, 4권, 광운

대학교 기업경영연구소, 209-244.

(1995), “지각된 환경특성과 조직특성이 대학관리자의 의도된 마케팅전략의 선택에

미치는 영향," 마케팅연구, 10권, 2호, 37-59, 한국마케팅학화.

중앙일보 (1998), ““97 전국 대학평가: 기부금 10 억 미만 21 개 대, 재단 전입금 기여

$5,8 \%$ 뿐, 교원보수 연세대가 최고," 9. 27.

Andreasen, Alan R. (1982), "Nonprofits: Check Your Attention to Customers," Harvard Business Review, May-June, 105-110.

Blong, J. and B. Bennett (1991), "Empty Wells: Resource Development in Tough Times,"Community, Technical, and Junior College Journal, 62 (August/September), 30-33.

Brittingham, Barbara E. and Thomas R. Pezzullo (1990), "The Campus Green: Fund Raising in Higher Education," ERIC Digest, www.ed.gov/ databases/ERIC_Digests/ed321705.html.

Bryson, J. (1988), Strategic Planning for Public and Nonprofit Organizations: A Guide to Strengthening and Sustaining Organizational Achievement, San Francisco: Jossey-Bass.

Burke, K. E. (1988), Institutional Image and Alumni Giving, Unpublished Doctoral Dissertation, University of Maryland, College Park, MD.

Carbone, R. F. (1986), Agenda for Research on Fund Raising, Monograph No.1, Clearing House for Research on Fund Raising, University of Maryland, College Park, MD.

Cook, Bruce W. and William F. Lasher(1996), "Toward a Theory of Fund Raising in Higher Education," The Review of Higher Education, 20, 1, 33-51.

Duronio, Margaret A. and Bruce A. Loessin(1991), Effective Fund Raising in Higher Education: Ten Success Stories, Jossey-Bass Publishers.

Fisher, J. L. and G. H. Quehl (1989), The President and Fund Raising, New York: American Council on Education and Mcmillan.

Glass, J. C. and K. L. Jackson (1998), "A New Role for Community College Presidents: Private Fund Raiser and Development Team Leader," Community College Journal of Research and Practice, 22(Sept.), 575-90.

Hamlin, A. and C. Hungerfolrd (1988-89), "How Private Colleges Survive a Financial Crisis: Tools for Effective Planning and Management," Planning for Higher Education, 17(2), 29-38.

Kelly, Kathleen S. (1991), Fund Raising and Public Relations: A Critical Analysis, Lawrence Erlbaum Associates, Inc., Publishers.

Kohli, Ajay K., Bernard J. Jaworski, and Ajith Kumar (1993), "MARKOR: A Measure of Market Orientaion," Journal of Marketing Research, Vol.30 (Nov.), 467-77.

Kotler, Philip and Karen F.A. Fox (1985), Strategic Marketing for Educational Institutions, 
Prentice-Hall, Inc., NJ : Englewood Cliffs.

Kotler, Philip and Alan Andreasen (1991), Strategic Marketing for Nonprofit Organizations, 4th ed., Prentice-Hall, Inc., NJ : Englewood Cliffs.

Kurzig, Carol M. (1981), "The Foundation Center and Its Role in Research," in J. David Ross, ed., Understanding and Increasing Foundation Support (New Directions for Institutional Advancement, No.11), pp.25-40.

Leslie, Larry L. and Garey Ramey(1988), "Donor Behavior and Voluntary Support for Higher Education Institutions," Journal of Higher Education, 59(2), 117-32.

Lindahl, Wesley E. (1992), Strategic Planning for Fund Raising, Jossey-Bass Publishers, CA San Francisco.

Lord, J. G. (1983), The Raising of Money: Twenty-Five Essentials Every Trustee Should Know, Cleveland, OH: Third Sector Press.

Lovelock, Christopher and Charles B. Weinberg (1977), Cases in Public and Nonprofit Marketing, Palo Alto, Calif : Scientific Press.

Marks, Linda(1987), "Improving Our Prospects: How Stanford Used a Massive Screening Program to Uncover New Major Gift Potential," CASE Currents, Nov./Dec.. www.case.org/currents/ freebies/prospects.htm.

Mueth, E. F. and I. Newman(1992), Corporate Philanthropy in American Higher Education: An Investigation of Attitudes Towards Giving, paper read at American Educational Research Association, San Francisco, April.

Nunnally, Jum C. (1978), Psychometric Theory. New-York: McGraw-Hill.

O'Shea, Catherine L. (1994), "A Stitch in Time," Case Currents, Dec., ww.case.org/ currents/freebies/stitchtime.htm.

Pfeffer, J. and G. R. Salancik(1978), The External Control of Organizations: A Resource Dependence Perspective. New York: Harper \& Row.

Ryan, Ellen (1989), "The Good, The Bad, and The Money: A Helpful Article on The Ethics of Planned Giving," Case Currents, October, http://www.case.org/currents /freebies/goodbad.htm.

Silberg, C. A. (1987), Factors Associated With the Philanthropic Behavior of Major Donors: A Proposal for a Research Study, Unpublished Doctoral Dissertation, University of Maryland, College Park, MD.

Snelling, B, W. (1986), "Recruiting, Training, and Managing Volunteers," in A. W. Rowland (ed.), Handbook of Institutional Advancement: A Modern Guide to Executive Management, Institutional Relations, Fund Raising, Alumni Administration, Government Relations, Publications, Periodicals, and Enrollment Management, San Francisco: Jossey-Bass.

Steinberg, R. (1987), "Nonprofit Organizations and the Market," in W. W. Powell (Ed.), The Nonprofit Sector: A Research Handbook, 118-138, New Haven, CT: Yale University Press.

Thompson, Dennis F.(1992), "Ethical Fundraising: An Educational Process," Educational Record, (Winter), 38-43.

Wise, Charles (1994), "Ready or Not?" Case Currents, Dec., www.case.org/currents/ freebies/ready.htm.

Wood, M. J. (1989), "The Four r's of Major Gift Solicitation," reid report(141), pp.1, 6. Pasadena, CA: Russ Reid Company.

Worth, Michael J, and James W. Asp, II (1995), "The Development Officer in Higher Education," ERIC Digest, www.ed.gov/ databases/ERIC_Digests/ed382106.html. 